\title{
Symbiosis of the Creative and the Developmental: Assessing Community Participation in the 2021 Odolu Theatre for Development (TFD) Project
}

\author{
Egwemi, O.P. (Ph.D). ${ }^{1} \quad$ Peter Ogohi Salifu ${ }^{1,2^{*}}$ \\ 1.Department of Theatre Arts, Kogi State University, P.M.B. 1008, Anyigba, Nigeria \\ 2.Department of Theatre and Film Studies, University of Nigeria, Nsukka
}

\begin{abstract}
Community participation is a major propeller in Theatre for Development (TFD) processes. This is given that TFD employs a collective approach to community problem identification, analysis of root causes, and creative formation of findings into performance skits to initiate discussion and social action using participatory drama. The performance aspect of TFD exercises is thus pivotal to the entire process and as such, community participation at this aspect is a catalyst for other aspects. This paper assesses community participation in the performance stage of the 2021 Odolu TFD project and examines its implication on the post-performance stage. Using both qualitative and quantitative designs, data is collected from Participant Observation, Key Informant Interview, and Focus Group Discussions and presented with the use of clustered bar charts, pie charts, and a line graph. Using Simple percentage, findings show that community participation in the performance aspect declined by $84 \%$ as the process progressed. Among other reasons, the decline is chiefly as a result of modifications in drama storylines, conflict with domestic activities, indisposition of community members, and inadequate use of folk media. The paper submits that there is a need for TFD practitioners to design strategies that enhance community participation as peculiar to respective communities and re-echoes the significance of harnessing available folk media towards desired results.
\end{abstract}

Keywords: Community, Participation, Theatre, Development, Theatre for Development

DOI: $10.7176 /$ RHSS/11-22-07

Publication date: November $30^{\text {th }} 2021$

\section{Introduction}

Experience over time in Theatre for Development (TFD) projects predisposes stakeholders to peculiar challenges and threats from target communities. Such challenges cut across issues of acceptance, integration, and community participation which may surface in varying degrees across different communities. Idoko and Onogu (2008) strongly agree that "the success of any theatre for development workshop is hinged on... the level of acceptance of the catalyst team and the readiness of community members to assume ownership of the [process and] outcome of the TFD projects". Whereas the problem of acceptance and integration could be considerably tackled at the stage of preliminary and advocacy visits, and consolidated by community entry strategies, that of active community participation may linger if strategic measures are not taken and may remain so throughout the project and even into post-performance and post-discussion stages where social or community action is required towards realizing the goals of the TFD project. Significantly, community participation is a necessary aspect of the exercise since it largely utilizes participatory drama and aims at conscientization.

TFD exercises comprise several stages such as community mapping, data collection, data analysis, prioritization, scenario formation, rehearsals, performance, and post-performance discussion, where community participation could be evaluated. But, this paper seeks to particularly assess community participation in the drama formation, rehearsal, and performance stage (tagged as 'the creative') and examine its implication on the postperformance stage, starting with discussion, then, necessary social/community action and sustainability of the initiative by host communities for developmental purposes. This shall be done with particular reference to the 2021 Odolu TFD project, undertaken by the Theatre Arts Department of the Kogi State University Anyigba, Nigeria.

TFD is a cardinal program in the academic curriculum of the Kogi State University Anyigba and has over time, championed the course of rural community conscientization, sensitization, and mobilization across Kogi State through which the process of attitudinal change, social change, and community development begins. Onogu (2021) in a briefing at the kick off of the project notes that in the two decades of the University's existence, 19 rural communities have played host to the University and benefited from the exercise. The 2021 Odolu project in this paper is the $19^{\text {th }}$.

Using the Odolu exercise as a point of reference, this paper posits that it is a problematic tendency to exclude community members from the creative and theatrical performance processes; scenario formation, rehearsals, and drama performances during community theatre/theatre for development projects, either partially; by relying on community members for data and excluding them in the translation of such data to performance, complacently; by yielding to a subtle decline of community members from the creative process, or intentionally by casting/role 
allocation without adequate inclusion and measures to guarantee robust community participation, especially in the gown and town inter-phase.

To guide the assessment of community participation in the performance aspect of the Odolu Community theatre project, this paper puts forward these questions:

- What was the rate/level of community participation in the creative aspect of the Odolu community theatre project?

- Did the rate of community participation in the drama formation and performance process decline or improve as the program progressed?

- If there was a decline or improvement, to what extent and why?

- What was the effect of the decline or improvement on the process?

\section{Empirical Review}

There are several opinions in the respect of community participation and the TFD process. While some believe that TFD can succeed without the active participation of community members in performance - wherein drama scenarios are formed and performed, community members watch and are allowed to participate in the discussion session, others hold that it is more effective to include community members in active participation in performance - wherein both community members and catalyst teams collaborate through all the stages. Teghtegh and Sokpo (2008) note that active participation of community members at the performance stage functions in making the drama more acceptable to the people and ensure participation of community members in the discussion session. Some TFD experts have relayed the impact of active community participation in the performance stage to the success of some of their TFD projects:

Mbachaga (2008) in "The Theatre for Development Approach to Researching and Communicating Tuberculosis Treatment Among the Rural Populace: The Logo Example" confirms that in the Logo (Benue State) exercise, "the women performed the drama skit alongside the drama activists for their community members and husbands to watch and at the plenary, concrete contributions were made by women". In the Abejukolo (Kogi State) exercise carried out in 2007, Alachi and Igbaba (2008) report that

an improvisational drama skit was developed with the people focusing on the major priority areas. Community members led by members of the cultural troupes rehearsed the drama with the assistance of the drama students and staff. The final performance was well attended. Prominent among those who participated in the final performance were the paramount ruler and his train of traditional rulers, LGA officials, doctors, civil servants, community leaders, and a large number of youths. After the performance, discussions were held in both group and plenary.

Although numerical data is not given by Alachi and Igbaba to authenticate this position, it is deductible that there was community participation to a promising degree. Notable in Mbachaga (2008), Alachi, and Igbaba's (2008) report is the side-by-side placement of community participation in the performance, the attendance at the performance, and the discussion that ensued. Showing that, they are in a cause and effect relationship - such that according to Alachi and Igbaba (2008), culminated into a fruitful deliberation session and drawing of a workable action plan with community members at the centre of it all. Alachi and Igbaba (2008) conclude their chapter on the Abejukolo Drama based Primary Health Care Intervention with a re-affirmation that "the issue of inter-sectoral coordination as a principle in Primary Health Care requires full community participation \{and that drama at the level of community participation is horizontal and culture friendly in view of problem identification and intervention".

Idoko and Onogu (2008) recount community participation in the Abocho exercise. They observe that the full participation of the people through their language and art forms expounds their world view and helps them reflect and debate on issues that have direct bearing to their lives and fuse them with the desire to better their conditions. It is such participation that creates an atmosphere for group activities and gets "the community members to act for themselves instead of looking forward to external solutions that may never come" (Idoko \& Onogu 2008). This explains the demonstrative illustration that if drama is acted and community members watch, they may also be tempted to wait and watch the development happen. But, if community members act the drama and discuss afterwards, it will be subconsciously established that the action necessary for change/development is collective. That is, that each one of them is a stakeholder in the process. Thus, the rate of participation in the drama has a ripple positive effect on this realization.

In the Benue Valley Theatre for Development and Health Intervention programme, Alachi and Sokpo (2008) maintain that "the idea of including community members in the drama was to encourage participation and to also develop their capacity to later use drama as a strategy to deal with health challenges in their community". The intervention did not succeed in ensuring active community participation in the drama and performance aspect and was criticized in this regard. Alachi and Sokpo (2018) admit that

even though some level of community participation was achieved, the development of the drama and song was done outside and imposed on the community; the only input 
from the community being their response to the baseline survey... the strong critique of the Night Halt activity was that it adopted the 'outside-in approach.

Perhaps, an understandable though unjustifiable reason for the failure in this regard could be that the catalyst team did not camp in the communities thus, resorting to the "outside-in approach". This flaw resulted partly in pitfalls of the programme such as the inability to 'empower and build the capacity of the communities with the drama and songs, the inability of the community members recruited at the last hour before the performance to master their roles, inability of the team to identify and train any existing base group to sustain the initiative, and inability to embark on follow up assessment and evaluation exercises after the programme (Alachi \& Sokpo 2008).

In the Naka TFD workshop of Benue state, Alachi and Aondowase (2008) confirm that the active participation of community members in the performance aspect (dance, songs, and drama) was a key point to the success of the exercise. The Kwagh-hir group of Naka and other volunteer community members actively participated in 'extensive rehearsals' which set them in good standing to make useful inputs, critique, and suggestions of the drama episodes after each rehearsal. For instance, "Girls and boys who participated in the rehearsals pointed out issues associated with promiscuity while men and women talked more about breastfeeding and family planning, malnutrition, prolonged labour, etc. Their contribution formed the background of most of the songs composed for the Kwagh-hir choruses" (Alachi \& Aondowase 2008). This shows that active participation in the drama formation and performance aspect was across gender and age-grades, thereby eliciting information about problems common to all levels of dwellers in the community. Their participation placed them in a comfortable position to make meaningful contributions at the plenary and assured the catalyst team that the community members had at that time, acquired the capability to employ TFD as a tool for addressing community problems. Thus, Alachi and Aondowase (2008) agree that "the involvement of the people from the very beginning of the rehearsals to the point where they can start to handle these activities themselves was impressive and rewarding".

Onogu and Menegbe (2008) talk about strategies put in place to ensure community participation in the Ogodo TFD project. The catalyst team from the Kogi State College of Education Ankpa embarked on basic drama skill acquisition for community members during advocacy visits. This skill acquisition "served as a prerequisite for community participation which was fundamental to the overall goal of the Ogodo project". This paper disagrees with their use of attendance at the skill acquisition exercise as a 'prerequisite' for eventual community participation but strongly agrees that such skill acquisition prepares community members who avail themselves ahead of the project. As well, it triggers the interest of members who are unable to be part of the skill acquisition, hence, the need to accommodate all at the kick-off of the project. Therefore, theatre activists rather than dominating the community theatre process, should "create an enabling environment for community members to acquire skills that will empower them to access and assess the drama-making process through active participation (Onogu \& Menegbe 2008) 'Active' here, connotes taking part in the creating, rehearsing, critiquing, and performing the drama. In the context of the foregoing, this paper insists that the role of community participation in performance cannot be overemphasized in TFD and the process of participatory development.

\section{Participatory Development Theory as a Framework}

Discourses and theorizations on participation, participatory approach, and participatory development theory gained impetus from the historical development and loopholes of Development theories like the Growth theories of the 1940s and 1950s, Modernization and Dependency theory of the 1960s which all channeled development planning towards economic concerns more than socio-cultural and agricultural development (El-Gack 2007). They were thus over time criticized for their incomprehensive handling of development and the exclusion of the people factor in the development process. The need for a holistic, people-driven, and people-centered development approach which will be peculiar to respective territories led to the participation approach championed by scholars like Paulo Freire in the 1970s, gaining popularity as an alternative development model and clamouring for the involvement of the people in the developmental process that concerns them. (El-Gack 2007).

Keough (1998) identifies some participatory development principles and practice - firstly, to approach each situation with humility and respect, thus:

Practitioners of participatory development must begin with a sense of humility; an awareness that each person brings unique skills and knowledge to a process and that the experience and formal education practitioners bring to a process is valuable but limited. People who have lived their whole lives in communities and who have a direct stake in the outcome of a project have vital knowledge to contribute. Those people will likely not share that knowledge if they are not made welcome to do so or if their knowledge and intelligence are not respected (Keough 1998).

TFD practitioners should understand the potential of local knowledge, adhere to democratic practice, acknowledge diverse ways of knowing, maintain a sustainability vision, put reality before theory, embrace uncertainty, recognize the relativity of time and efficiency, take a holistic approach, and exercise an option for the community (Keough 1998). All of these are to incorporate community ideas and maximize potentials inherent in participation as against all rigid dogmata. M.S Dinbabo (2003) aptly captures the spectrum of Participatory 
Development from the perspective of Slocum, Wichhart, Rocheleau, and Thomas-Slayter (1995) to be a people's active involvement in decision making and the 'implementation of processes, programs and projects that affect them'. Within this framework, this paper assesses the level of community participation in the 2021 Odolu Theatre for Development (TFD) project, investigating the reasons for and effect of the rate of participation on the eventual outcome of the project.

\section{Methodology}

This research is a case study analysis of the 2021 Odolu Theatre for Development Project. Because of the depth of analysis and the necessity of numerical specificity, both qualitative and quantitative designs are partly employed to analyze and present data. Data is collected through Participant Observation, Key Informant Interview, and Focus Group Discussions. Data is presented with the use of clustered bar charts, pie charts, and a line graph. The simple percentage is used to determine the rate of decline in community participation.

\section{Data Presentation and Interpretation}

The community theatre project comprises of several stages such as community mapping, data collection, data analysis, prioritization, scenario formation, rehearsals, performance, and post-performance discussion, etc. However, this paper assesses community participation at the drama performance aspects which has been otherwise tagged 'the creative' in this paper. This includes scenario formation, rehearsal, and the performance stages. Meanwhile, it is imperative to give an overview of the stages of the Odolu project.

On arrival and settling in, community mapping was embarked upon by members of the University team in a familiarization stroll; noting landmarks and boundaries. The map guided the team in the distribution of members to cover several areas of the community for data collection. Thus, the team afterwards adopted the flooding approach, wherein groups were created to reach out to community members in their homes, streets, and corners for interaction and data collection. Significantly, this was the first participation point of the community members who in this case were the respondents. Community members further participated in the validation of data collected at the end of the data collection exercise as well as the prioritization of community problems that the data collection exercise listed. The community problems were therefore listed in their order of impact from the perspective of the community members as follows: lack of quality education, insufficient primary health care, and lack of potable water, absence of electricity supply, non-functional market, teenage pregnancy, restiveness, and disunity among youths. With this information, members of the University team were grouped into 5 to brainstorm and form drama scenes. Evening entertainment sessions that featured dance competitions, role play, riddles, and jokes were effective in assembling the people, integrating the team with the community, and sustaining their interest in data validation and prioritization. 32 community members were voluntarily and unevenly distributed across the 5 groups (see figure 2). Group 1 handled the case of lack of quality education, Group 2 worked on insufficient primary health care and lack of potable water, Group 3 formed a scenario on the subject of electricity, Group 4; non-functional market and Group 5; restiveness and disunity among youths. Each group produced drama episodes that highlighted the identified problems.

\subsection{Drama Scenarios}

In episode 1, a teacher moves towards the classroom where he teaches. On his way, he laments the deplorable status of his teaching job and other factors that are responsible for the substandard system of education in the Odolu community. He enters the class and is accosted by Bonsu, a male student who bullies him out of the classroom with the support and cheering of other students. The students are happy that the class will no longer hold and decide to go home. On their way home, they meet Donsu who was as notorious as Bonsu but had turned a new leaf and given attention to his education. He tells them how much his new attitude to education has helped him learn better, guaranteeing him a good life and promising future.

Episode 2 opens at the community Primary Health Care centre. Two nurses discuss the issue of understaffing and lack of facilities in the clinic. They are interrupted by a lady who runs into the clinic, complaining of a "running stomach". The nurses are unable to give her any treatment as the drug is not available. A pregnant woman in labour is also brought in by her husband and mother but is told that the doctor is to be called on the phone to be informed of the situation since he is not resident in the community as a result of other factors that make the place unsuitable for him. The mother and husband decide to take their pregnant ward to Ida, another town where they could have better treatment. The mother rushes back to the Odolu clinic after a moment, crying and harassing the nurses. She insisted that their inefficient services and the bad road between Odolu and Ida had claimed the life of her pregnant daughter.

Episode 3 begins with a meeting of community members and their elders. Selected community stakeholders inform the entire community of the progress they have made so far to ensure that electricity is restored in the community. They brainstorm with suggestions from several community members about how community members can contribute to the process to achieve a better and faster result. The youths resolve to play their part by turning 
out in their numbers for all tasks that will be assigned to them in this regard. They further highlight businesses they would venture into when electricity is restored to ensure a better standard of living in their community.

In episode 4, Two Odolu community members are on their way to sell their goods at the Okutu market (a neighbouring community). They are stopped by another community member who educates them on the implications of their export on the Odolu community market and the risk they expose themselves to in the process, such as bad road, transport cost, and the possibility of low-cost selling. They resolve to buy and sell in the Odolu community market to strengthen it before considering profitable inter-community trade modalities.

In episode 5, Ajeka defies his father's admonition about the company he keeps to the utter dismay of his father and Edogbanya, his father's friend. Both men complain bitterly about the attitude of youths in the community and the consequences of their misbehaviour. In a second scene, Ajeka harasses a boy on the street and snatches his phone. Back home and in another scene, Ajeka corners Ajifa, a fourteen years old girl who hawks oranges. He lures her with money and gets her pregnant. Ajifa is not remorseful of her actions and talks back at her mother; she maintains that her attitude is a result of her poor upbringing which has been solely the responsibility of her parents. Ajifa has complications at childbirth and develops Vesicovaginal Fistula (VVF). Ajeka in his next street raid is caught and handed over to the community vigilante group.

Drama scenarios from all the episodes were to be created by both members of the catalyst group and community members as distributed into the respective groups. The data presented in the next session, however, accounts for the actual ratio of community participation through the scenario formation, rehearsal and performance stages.

\subsection{Initial Participants (IP)}

Figure 1: Initial Participants (IP)

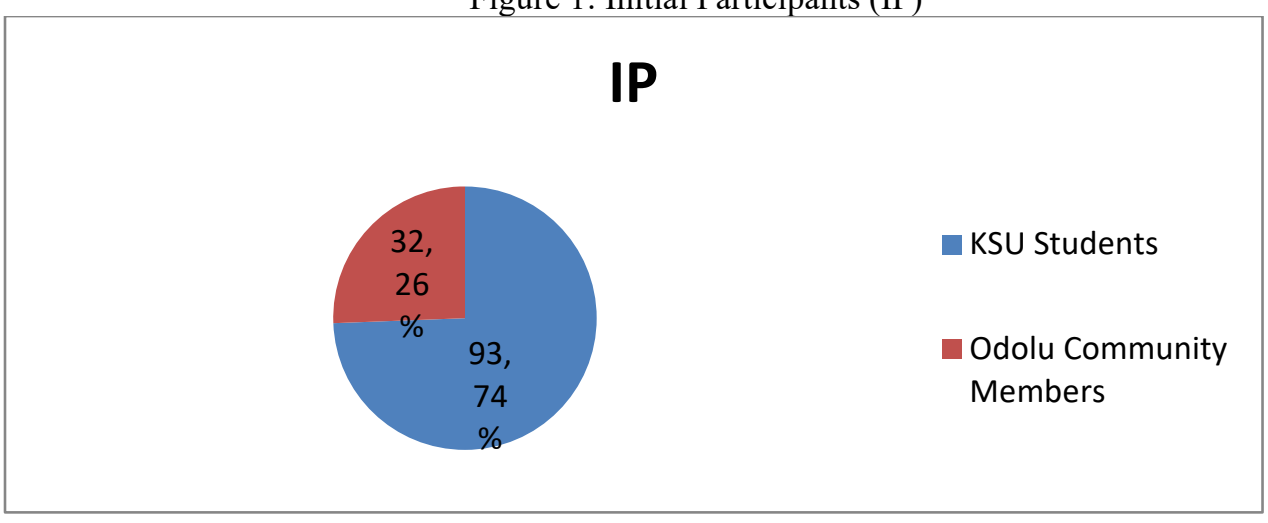

Total number of Initial Participants (IP)

Figure 1 above shows that 32 persons representing 26\% of the total population make up the Total Number of Initial Community Participants (TNICP) while 93 persons representing 74\% of the total population were student members of the University Student participants involved in the performance aspect of the Odolu TFD project.

\subsection{Initial Group Participants}

Figure 2: Initial Group Participants (IGP)

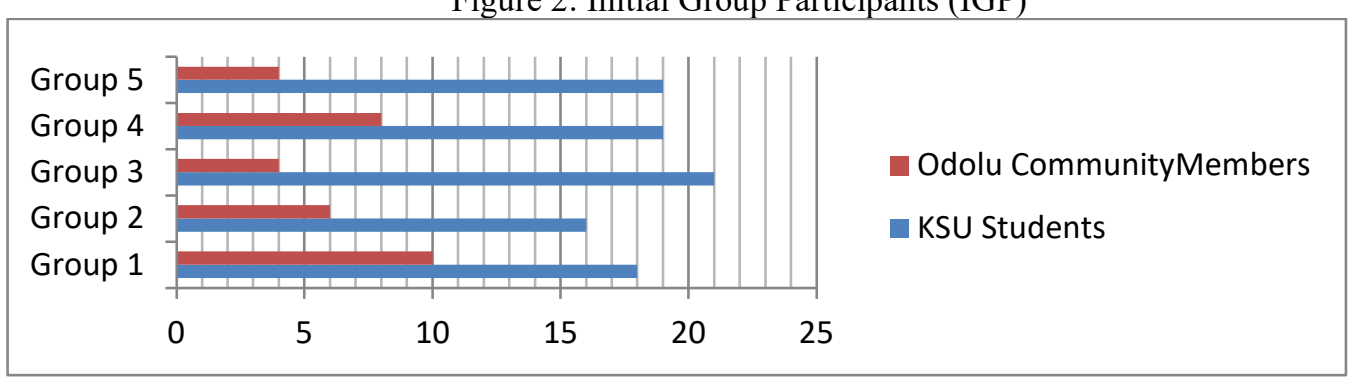

Initial Group Participants (IGP)

Figure 2 shows the initial distribution ratio of the Kogi State University (KSU) students-team and the Odolu community members. Group 1 consisted of $18 \mathrm{KSU}$ students and 10 Odolu community members. Group 2 had 16 KSU students and 6 Odolu community members. Group 3 was made up of $21 \mathrm{KSU}$ students and 4 Odolu community members, group 4 was made up of $19 \mathrm{KSU}$ students and 8 Odolu community members while group 5 had 19 KSU students and 4 Odolu community members. Thus, the total number of KSU student-team $=93$, while the total number of Odolu community members distributed into groups $=32$. 


\subsection{Actual Group Participants}

Figure 3. Actual Group Participants (AGP)

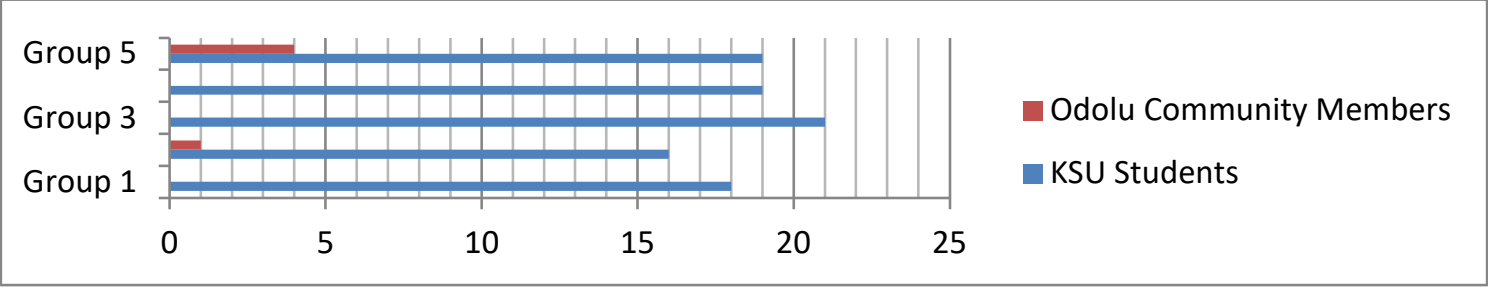

Actual Group Participants (AGP)

Figure 3 shows the actual number of persons that were involved in the eventual performance. In group 1, 18 KSU students remained active 0 Odolu community members joined in the rehearsed performance. In group 2, 16 KSU students were active while 1 Odolu community member joined in the active performance of the rehearsed scenario. In group 3, $21 \mathrm{KSU}$ students performed while 0 Odolu community members joined in the performance. In group 4, $19 \mathrm{KSU}$ students staged the rehearsed scenario while no rehearsed community member took part. In group 5, $19 \mathrm{KSU}$ students staged the rehearsed scenario alongside 4 Odolu community members. The relationship between the Initial Group Participants (IGP) and Actual Group Participants (AGP) of the Odolu Community population of participants is shown in Figure 4 below:

Figure 4: IGP vs AGP

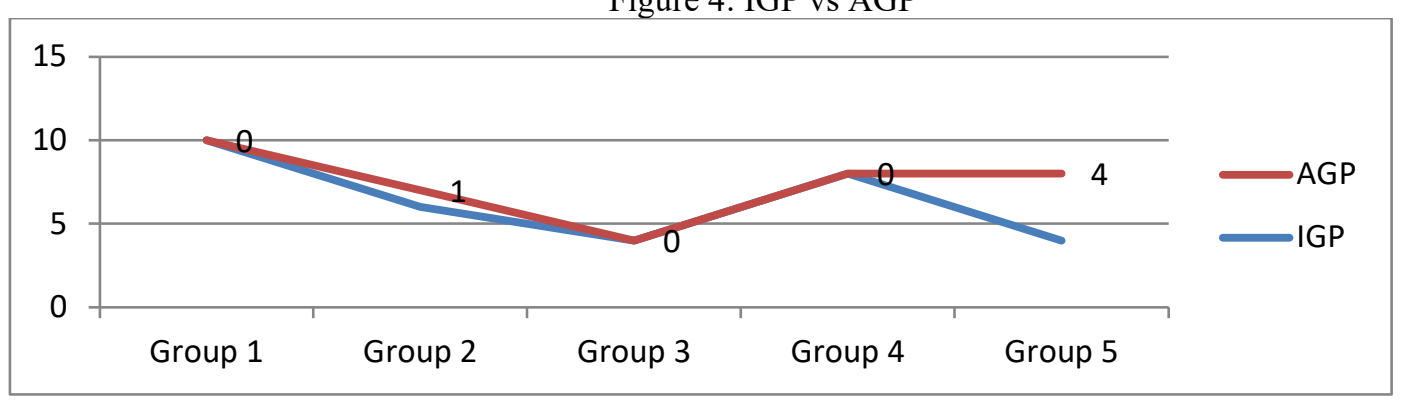

Relationship between IGP and AGP of the Odolu community participant Population

Figure 4 above shows that Group 1 with an Initial Community membership of 10 persons had 0 at the rehearsed performance. Group 2 with an initial community membership of 6 persons had 1 person at the rehearsed performance. Group 3 with an initial community membership of 4 persons had none at the rehearsed performance. Group 4 with an initial community membership of 8 persons had 0 at the rehearsed performance while Group 5 with an initial community membership of 4 persons had 4 persons at the rehearsed performance.

\subsection{Percentage of Actual Participants (AP)}

Figure 5. Actual Participants

\begin{tabular}{|l|l|}
\hline AP & KSU Students \\
$93,95 \%$ & $\begin{array}{l}\text { Odolu Community } \\
\text { Members }\end{array}$ \\
\hline
\end{tabular}

Actual Participants (AP)

Figure 5 shows that 5 participants representing $5 \%$ of the total number of participants make up the Total Number of Actual Community Participants (TNACP) while 93 persons, representing $95 \%$ of the total participant population were University student team members.

\subsection{Percentage Rate of Decline for Odolu Community Participants}

A comparison of Figure 1 and Figure 4 shows that there was a significant decline in the number of Odolu community member participants. Using simple percentage, the rate of decline is shown below:

Given in Figure 1, 2 and 3, 
Total Number of Initial Community Participants $($ TNICP $)=32$

Total Number of Actual Community Participants (TNACP) $=5$

Total Percentage Rate of Decline $($ TPRD $)=\frac{\text { TNICP-TNACP }}{\text { TNICP }} \times \frac{100}{1}$

$$
\mathrm{TPRD}=\frac{27}{32} \times \frac{100}{1}=84 \%
$$

It is also pertinent to ascertain the Group Percentage Rate of Decline (GPRD) from each group that has contributed to the TPRD (84\%).

5.7. Group Percentage Rate of Decline (GPRD)

GPRD $=$

$\frac{\text { Number of Initial Community Participants in Group (NICPG)- Number of Actual Community Participants in Group (NACPG }}{\text { Total Number of Initial Community Participants (TNIP }} \times \frac{100}{1}$

$$
\begin{gathered}
\text { Group 1: } \frac{10}{32} \times \frac{100}{1}=31 \% \\
\text { Group 2: } \frac{5}{32} \times \frac{100}{1}=16 \% \\
\text { Group 3: } \frac{4}{32} \times \frac{100}{1}=12 \% \\
\text { Group 4: } \frac{8}{32} \times \frac{100}{1}=25 \% \\
\text { Group 5: } \frac{0}{32} \times \frac{100}{1}=0 \% \\
\text { TPRD }=\text { sum of GPRD (Group 1, 2, 3, 4, and 5) }=84 \% .
\end{gathered}
$$

The above shows that there was a Total Percentage Rate Decline (TPRD) of $84 \%$ in the participation of Odolu Community members between the beginning of scenario formation and actual performance. $31 \%$ of the decline resulted from the decline of community members allocated to Group 1. Group 2 accounts for a 16\% decline, there is a $12 \%$ decline in Group 3, and Group 4 is responsible for a $25 \%$ decline while there is a $0 \%$ decline in Group 5.

\section{Discussion/Analysis}

Focus Group Discussion (FGD) with Group leaders and selected Group members from the University student team and Key Informant Interview with selected Odolu community members revealed some of the causes of the high rate of decline in community participation at the drama formation, rehearsal, and performance stages from the respective perspectives of the two categories of participants.

In group 1, the Group leader from the student team states that the community participants in the group declined on the second day of rehearsals following the modification of their storyline and characters during the critique of their presentation after the first day of rehearsal. In their assessment, time constraints and the modification made it impossible to accommodate their 10 community member participants who were within the age range of 5 to 10 years and played the role of primary school pupils in their defunct storyline. The adjusted version of their skit required characters to play as Senior Secondary School students, a role that in their assessment would not be convincingly interpreted by the community participants in the group.

The student team leader of Group 2 reveals that out of the 6 community members at the initial distribution, 4 attended the first rehearsal. Subsequently, only 1 participant remained. She observes that the others of younger age were always busy with domestic activities and could not participate.

In Group 3, the Group leader attributes the decline in community participation to loss of interest following modification of storyline and the rehearsal time which was unfavourable to the schedule of community members.

A student participant in Group 4 revealed that the community members in the group were interested in playing particular roles with improvised lines and actions that appeal to them for theatric stunts, to gain acceptance and applaud from their community fan base, but that was not relevant to the goal of the skit formed. They were resistant to modifications and adjustments made to the skit since it eliminated their 'star roles' and 'robbed' them of opportunities to impress their fans. The Group leader confirmed that consequently, "the turn up was very poor as they came for rehearsals on days they liked. None of the members participated on the performance day" (FGD February 26, 2021).

The Group leader of Group 5 recounts the active participation of all community member participants in the group as a major factor that contributed to the success of their presentation. He adds that all hands were on deck and collective ideas from the student team and community members in the group, was a major boost. This reflects in the $0 \%$ decline of community participants recorded in the group. Other factors mentioned at random during the FGD include shyness, lack of confidence, lack of prior experience in drama formation and acting, and personal work schedules of community members.

Key Informant Interview revealed the perspective of some community members. For instance, Stephen Monday Abu applauded the entire initiative and notes that community participation would have been enhanced 
with the use of community folk media especially, the community town crier system (Interview). Abu's position here has been reiterated by scholars and practically employed with success in TFD programmes. Alachi and Igbaba (2008) explain that "folk media are valuable... not [only] because they convey 'information' but because they contribute to the 'domestication' of development". The folk media methodology is potent in synergy with other suitable TFD methodologies to ensure community mobilization and participation. Ediri and Teghtegh (2008) recount the efficacy of folk media in the exercise carried out by the Liverpool Associates on Tropical Health (LATH) in Benue, in 2001 - it was used "to create an enabling atmosphere and as a rallying point for community action. The aim was to gain acceptance through local media while at the same time popularizing the program (Ediri and Tegtegh 2008). Conflict of activities was another major concern as some community members grappled with attending the community theatre activities and their domestic and work activities. A salient area mentioned by an informant is the use of the English language by the moderator at the evening gatherings of the catalyst team and community members. Though an Igala interpreter mediated, a section of community members preferred a direct interaction in the Igala language. To a little degree, it is also gathered that some community members had their reservations about attending the activities as the camp and performance ground was a popular location for Christian Religious Activities, popularly known in the community as "Tabernacle".

The level of community participation in the foregoing affected the post-performance discussion. Though the performance was fairly attended by community members who affirmed the themes and facts in the episodes, the discussion could have been more engaging as it is a strategic medium of reaching resolutions and charting action plans towards social and community action required to achieve the results of the Theatre for Development (TFD) exercise.

\section{Conclusion}

This paper has assessed community participation in the drama formation, rehearsal, and performance stages of the 2021 Odolu community theatre exercise carried out by the Theatre Arts Department of Kogi State University Anyigba. It is established that community members attended to an appreciable degree the evening entertainment sessions organized to integrate the catalyst team and the community. They participated in dancing competitions and riddle/joke sessions. Sustained by such interest, they were also available for data analysis and problem prioritization which always followed evening entertainments. The community members were however relatively apathetic to participation in drama formation, rehearsal, and performance. Thus, there was an $84 \%$ decline in the number of community participants who were to be part of the drama formation and performance groups. The low community level participation in this performance aspect negatively affected their input at the post-performance discussion and posed a challenge to developing a people-centered action plan. It has also made it uncertain that the people acquired sufficient capacity to sustain the initiative in their community.

\section{Recommendations}

The following recommendations are given for the attention of TFD practitioners, organizations, and institutions that may embark on future projects. They should:

- Intensify efforts and strategies towards effective community participation.

- Design frameworks that can accommodate workable training and orientation for community members to enhance their understanding of the TFD initiative and the role of their active participation in the process.

- Deploy strategic intelligence in handling subtle decline of community participants and draw workable schedule that would minimize conflict of activities.

- Continually harness all available peculiar folk media towards propagating the initiative and attracting community participation.

- Insist on the use of the host community's dominant language by moderators and facilitators at all stages.

\section{References}

Alachi, J.A. and Aondowase, B. (2008). Community Participation Towards Safe Motherhood and Child Survival: The Example of Community Theatre Workshop Held in Naka, Benue State. Theatre for Development in the Benue Valley. Ed. James Atu Alachi. Oturkpo: Bookmakers Publishing, 50-69.

Alachi, J.A. and Sokpo, L. (2008). Theatre for Development and Health Intervention in the Benue Valley: The BHF DRF and DE Programme. Theatre for Development in the Benue Valley. Ed. James Atu Alachi. Oturkpo: Bookmakers Publishing,30-49.

Alachi, J.A. and Igbaba S.O. (2008). Drama Based Primary Health Care Intervention in Abejukolo Area of Kogi State. Theatre for Development in the Benue Valley. Ed. James Atu Alachi. Oturkpo: Bookmakers Publishing, 111-126.

Dinbabo, Mulugeta. (2003). Development Theories, Participatory Approaches and Community Development. Unpublished paper. Bellville: Institute for Social Development, University of the Western Cape, 2003.

Ediri, J. and Teghtegh, D. (2008). Theatre for Development and Community Education on HIV/Aids: The Benue 
LATH Experience. Theatre for Development in the Benue Valley. Ed. James Atu Alachi. Oturkpo: Bookmakers Publishing, 15-29.

El-Gack, N. (2007). Participatory Approaches to Development: An Analysis of the Experiences of Development Projects in Sudan. Ph.D Thesis, Massey University, Palmerston North, New Zealand.

Idoko, O.E. and Onogu W.S. (2008). Drama as a Tool for Effective Awareness Creation on Health Related Issues in Rural Areas in Kogi State: The Abocho Example. Theatre for Development in the Benue Valley. Ed. James Atu Alachi. Oturkpo: Bookmakers Publishing, 127-140.

Keough, Noel. (1998). Participatory Development Principles and Practice: Reflections of a Western Development Worker. Community Development Journal. Vol. 33 No. 3, 187-196.

Mbachaga, J.D. (2008). The Theatre for Development Approach to Researching and Communicating Tuberculosis Treatment Among the Rural Populace: The Logo Example. Theatre for Development in the Benue Valley. Ed. James Atu Alachi. Oturkpo: Bookmakers Publishing, 70-82.

Onogu, W.S. and Menegbe, A.D. (2008). Community Theatre: A Tool for the Enhancement of Primary Health Care in Ogodo Community. Theatre for Development in the Benue Valley. Ed. James Atu Alachi. Oturkpo: Bookmakers Publishing, 97-110.

Teghtegh, D. and Sokpo. L. (2008). TFD and Social Development: The Benue Health Fund (BHF) IEC Programme. Theatre for Development in the Benue Valley. Ed. James Atu Alachi. Oturkpo: Bookmakers Publishing, 8396.

\section{Acknowledgements}

We thank Professor Williams Onogu, Dr. Jonathan Okpanachi, Mr. Philip Akoje, Mr. Adukwu Martins, and Mrs. Faith Salami who are all staff members of the Department of Theatre Arts, Kogi State University, Anyigba, Nigeria, for their roles as staff team members of the 2021 Odolu Community Theatre Project. We thank Professor Emmy Idegu (University of Calabar, Nigeria) for his solidarity and support. We thank 300 level students (2019/2020 academic session) of the Department of Theatre Arts, Kogi State University who were the catalyst group of the project for their creativity in the formation and interpretation of the drama scenarios upon which the discussion was anchored. Among the student team members, Hamza Jibrin (Leader, Group 1), Martha Enyo-Ojo Okpe (member, Group 1), Blessing Akor (leader, Group 2), Fidelia Amanyi (leader, Group 3), Mercy Eyojo (member, Group 4), and Stephen Olugbemi (leader, Group 5), provided useful information as active participants in the Focus Group Discussion. Also, we thank Stephen Monday Abu and Dan Abu (Odolu Community members) for useful discussions. We thank Jide Yakubu for support and acknowledge the insight of other staff members at the Department of Theatre Arts, Kogi State University, Anyigba; Miss. Blessing Ikwuji, Mr. Onuche Godwin, and Mr. Samuel Alidu. We also thank Mr. Iye Samuel (Camp power house technician of the project) for his technical assistance. 